JURNAL PENDIDIKAN, p-ISSN 2715-095X, e-ISSN 2686-5041

Volume 30, No.2, Juli 2021 (283-290)

Online: http://journal.univetbantara.ac.id/index.php/jp

\title{
Meningkatkan Penguasaan Mata Pelajaran PKn tentang Budaya Indonesia melalui Penugasan dengan Diskusi Kelompok pada Siswa Kelas IV SD Negeri Karanglincak
}

\begin{abstract}
Sugino
SD Negeri Karanglincak, Kecamatan Kragan, Kabupaten Rembang, E-mail:sugino.kragan@gmail

Received: April 12, $2021 \quad$ Accepted: April 24, $2021 \quad$ Online Published: Juni 26, 2021

Abstrak: Tujuan penelitian ini adalah mendeskripsikan peningkatan hasil belajar siswa Kelas IV SD Negeri Karanglincak Semester 2 Tahun Pelajaran 2017/2018 pada mata pelajaran PKn tentang budaya Indonesia. Penelitian Tindakan Kelas (PTK) menggunakan Model Siklus dan berlangsung dalam 2 siklus, yaitu Siklus I dan Siklus II. Hasil penelitian ini adalah penerapan penugasan dengan metode diskusi kelompok di dalam kelas dan di luar kelas meningkatkan hasil belajar siswa. Hasil belajar pada Kondisi Awal adalah nilai rata-rata sebesar 64,46 dan ketuntasan sebesar 14,28\%. Hasil belajar pada Siklus I adalah nilai rata-rata sebesar 74,28 dan ketuntasan sebesar $60,71 \%$. Hasil belajar pada Siklus II adalah nilai rata-rata sebesar 84,46 dan ketuntasan sebesar $96,42 \%$.

Kata-kata Kunci: Budaya Indonesia, Penugasan, Diskusi.

\section{Improving the Mastery of Civics Education about the Culture of Indonesia trough Assignment with Group Discussion to the 4th Grade Students of Karanglincak Elementary School}

\section{Sugino}

SD Negeri Karanglincak, Kecamatan Kragan, Kabupaten Rembang, E-mail:sugino.kragan@gmail

\begin{abstract}
The purpose of this research is describing the improvement of the 4th Grade learning outcome Students' of Karanglincak Elementary School on Second Semester 2017/2018 Year Academic in Civic Education about the culture of Indonesia. This Class Action Room (CAR) is using Cycle Model and going on 2 cycles; First Cycle and Second Cycle. The result of this research is the application of the assignment with group discussion inside and outside the class improved of the students' learning outcome. The learning outcomes on the Early Condition are the average at 64,46 and the completeness at 14,28\%. The learning outcomes on the First Cycle are the average at 74,28 and the completeness at 60,71\%. The learning outcomes on the Second Cycle are the average at 84,46 and the completeness at $96,42 \%$.
\end{abstract}

Keywords: the culture of Indonesia, Assignment, Discussion.

\section{Pendahuluan}

Guru yang efektif adalah mereka yang mampu memfasilitasi siswanya berhasil mencapai tujuan pembelajaran. Di samping itu, guru adalah tenaga profesional yang bertugas merencanakan dan melaksanakan pembelajaran, menilai hasil pembelajaran, melakukan bimbingan dan pelatihan serta melakukan penelitian dan pengabdian kepada 
masyarakat. Dengan demikian, guru dengan kompetensi pedagogik dan kompetensi profesional menggunakan media belajar secara optimal dan profesional. Dewasa ini, telah banyak upaya yang telah dilakukan sebagai bentuk usaha dalam meningkatkan profesionalitas guru dalam menghadapi teknologi global seperti sekarang ini (Suwarto, 2017). Upaya tersebut dimulai dengan dasar hukum Undang-Undang Nomor 14 Tahun 2005 tentang Guru dan Dosen dan dilanjutkan dengan program sertifikasi maupun pembentukan kegiatan guru (Musyawarah Guru Mata Pelajaran dan Kelompok Kerja Guru) dan kepala sekolah (Kelompok Kerja Kepala Sekolah).

Penulis dalam melaksanakan tugas sebagai guru mata pelajaran di Sekolah Dasar (SD) masih banyak mengalami berbagai hambatan, terutama dalam mata pelajaran Pendidikan Kewarganegaraan (PKn) di Kelas IV tentang Budaya Indonesia. Selama ini metode ceramah merupakan suatu pilihan yang paling tepat dan mudah untuk diterapkan. Rutinitas pembelajaran yang demikian sangat tidak mendukung prestasi belajar siswa. Dengan pola pembelajaran yang serba verbalistis tersebut, siswa kurang berminat untuk mengikuti proses pembelajaran, sehingga menjadi jenuh, bosan dan cenderung pasif. Kondisi belajar siswa yang demikian memang benar adanya karena guru dalam menyampaikan materi terkesan monoton. Sedangkan menurut Mujinem (2012), pemilihan metode mengajar yang tepat meningkatkan motivasi siswa dalam mengikuti pembelajaran, sehingga mencapai kompetensi yang diharapkan. Hal tersebut menunjukkan bahwa pemilihan metode ceramah tidak tepat.

Menurut Syafril (2019), PKn adalah mata pelajaran yang disusun secara sistematis, komprehensif dan terpadu dalam proses pembelajaran menuju kedewasaan dan keberhasilan dalam kehidupan di masyarakat. Sedangkan menurut Warsini (2021), PKn adalah mata pelajaran yang selalu ada di semua jenjang pendidikan formal, mulai dari pendidikan dasar sampai pendidikan tinggi sebagai mata pelajaran inti. Mengingat karakteristik dan pentingnya tersebut, maka pembelajaran hendaknya interaktif, sehingga siswa benar-benar terlibat. Pada praktiknya, hal tersebut tidak terpenuhi karena PKn dianggap normatif. Oleh karena itu, metode diskusi tepat dalam pembelajaran PKn.

Pada jenjang pendidikan dasar di Sekolah Dasar (SD), PKn disajikan dengan alokasi waktu selama dua jam pelajaran. Sesuai dengan pembagian tugas, maka Kepala Sekolah memilih sebagai guru pelajaran PKn. Dengan berbagai kewajiban sebagai Kepala Sekolah, tugas guru pelajaran tersebut tidak optimal karena berbagai kesibukan agenda dinas. Tugas tersebut terbengkalai dan prestasi belajar mengecewakan.

Berdasarkan penguasaan konsep siswa Kelas IV SD Negeri Karanglincak tentang budaya Indonesia masih sangat rendah. Dari hasil tes formatif dalam pembelajaran awal, nilai rata-rata kelas hanya mencapai 64,46 dengan tingkat ketuntasan 14,28\%. Adapun jumlah siswa yang tuntas dalam pembelajaran hanya 4 siswa, sementara siswa yang belum tuntas dalam pembelajaran tersebut sejumlah 24 siswa. Oleh karena itu, penulis merasa sangat perlu untuk segera mengambil tindakan agar dapat mengatasi ketidaktuntasan belajar siswa dan juga faktor rendahnya prestasi belajar serta sikap masa bodoh siswa terhadap pembelajaran. Hasil diskusi dengan rekan sejawat terungkap beberapa masalah yang terjadi dalam pembelajaran PKn tentang budaya Indonesia di Kelas IV SD Negeri Karanglincak, yaitu 1) Tingkat penguasaan siswa terhadap materi pelajaran masih rendah, 2) Siswa tidak 
dapat mengungkapkan sebuah pendapat, 3) Siswa takut mengajukan suatu pertanyaan, 4) Guru masih kurang menguasai kelas dan 5) Ketepatan penggunaan peraga masih kurang.

Keterlibatan siswa yang kurang untuk mengikuti pembelajaran PKn perlu mendapatkan perhatian sehingga saat kegiatan belajar mengajar berlangsung dengan lancar dan baik, fasilitas yang menunjang dalam proses kegiatan belajar mengajar seperti perpustakaan yang dilengkapi buku PKn yang berkaitan sesuai dengan materi pembelajaran sangat membantu keberhasilan pembelajaran PKn. Model pembelajaran yang diterapkan dalam pembelajaran PKn baiknya menggunakan model pembelajaran yang aktif yang ditandai oleh dua faktor, yakni adanya interaksi antara antara guru dan siswa, dan berfungsi secara maksimal meliputi karsa, emosi, indera dan nalar (Wagiyem, 2021).

Kemampuan siswa dalam pemahaman pelajaran dipengaruhi dari model pembelajaran yang sesuai, sehingga mampu mencapai tujuan yang ditetapkan. Berbagai macam model pembelajaran bisa menjadi salah satu pilihan untuk guru agar proses belajar dan mengajar di kelas berlangsung secara efektif serta optimal. Penggunaan pembelajaran kooperatif bisa menjadi salah satu alternatif pembelajaran yang efektif (Wagiyem, 2021).

Dari berbagai masalah yang telah dikemukakan di atas, yang dapat penulis perbaiki hanya masalah yang berkaitan dengan peningkatan prestasi belajar siswa dan perbaikan pada kesalahan pola pembelajaran mata pelajaran PKn. Oleh karena itu, penulis segera mengambil langkah untuk mengadakan perbaikan pembelajaran dengan harapan agar siswa lebih mudah memahami dalam menerima konsep pembelajaran PKn tentang budaya Indonesia. Untuk mengatasi masalah rendahnya prestasi belajar siswa tersebut, penulis melakukan Penelitian Tindakan Kelas (PTK) dalam mata pelajaran PKn tentang Globalisasi secara umum dan tentang budaya Indonesia secara khusus. Tindakan tersebut adalah penugasan dengan diskusi kelompok.

Menurut Madjid (2011: 141), diskusi berasal dari bahasa Latin, yaitu discutere yang berarti membeberkan masalah, sedangkan metode diskusi adalah metode belajar dengan berupaya memecahkan masalah yang dihadapi, baik dua orang atau lebih yang masingmasing mengajukan argumentasinya untuk memperkuat pendapatnya. Dalam metode diskusi, masing-masing menghilangkan perasaan subyektivitas dan emosional, sehingga tidak mengurangi bobot pikir dan pertimbangan akal yang sebagaimana mestinya.

Dalam diskusi, siswa belajar memecahkan masalah, baik secara individual maupun dalam kelompok (Syah, 2007: 205), tercapai pendapat atau keputusan bersama (Masitoh, 2009: 118) dan penguasaan masalah secara mendalam. Kelebihan dari tindakan dengan diskusi adalah masalah dapat dipecahkan dengan berbagai jalan, tidak hanya satu jalan, saling mengemukakan pendapat secara konstruktif, sehingga diperoleh keputusan yang lebih baik dan melatih mendengarkan pendapat orang lain sekalipun berbeda dengan pendapatnya sendiri dan membiasakan sikap toleran (Djamarah, 2010: 199). Selain itu, metode diskusi merangsang dan menciptakan kemampuan belajar siswa secara langsung, khususnya dalam mengeluarkan pendapat atau gagasan, sehingga pembelajaran menjadi efektif (Sahnun, 2018).

Menurut Sanjaya (2011: 158), langkah-langkah dalam pembelajaran dengan diskusi kelompok, yaitu 1) merumuskan tujuan yang ingin dicapai,baik tujuan umum maupun khusus, 2) menentukan jenis diskusi sesuai dengan tujuan yang ingin dicapai, 3) menetapkan masalah yang akan dibahas dan 4) mempersiapkan segala sesuatu yang berhubungan dengan teknis pelaksanaan diskusi. Sedangkan tujuan metode diskusi menurut Madjid (2011: 141), yaitu 1) melatih mengembangkan keterampilan bertanya, berkomunikasi, berkomunikasi, menafsirkan dan menyimpulkan bahasan, 2) melatih dan 
membentuk kestabilan sosio-emosional, 3) mengembangkan kemampuan berpikir sendiri dalam memecahkan masalah, sehingga tumbuh konsep yang lebih positif, 4) mengembangkan keberhasilan dalam menemukan pendapat, 5) mengembangkan sikap terhadap isu-isu kontroversial, 6) melatih berpendapat tentang suatu masalah.

\section{Metode Penelitian}

Penelitian ini merupakan Penelitian Tindakan Kelas (PTK) dan berlangsung dalam dua siklus. Subyek penelitian adalah siswa Kelas IV SD Negeri Karanglincak, Kecamatan Kragan, Kabupaten Rembang, sebanyak 28 anak. Tindakan adalah penugasan dengan metode diskusi kelompok. Tindakan dilakukan pada mata pelajaran PKn tentang budaya Indonesia pada Semester 2 Tahun Pelajaran 2017/2018. Siswa dibagi menjadi beberapa kelompok dan diberikan tugas. Siswa mengerjakan tugas dengan diskusi kelompok. Sumber data adalah hasil belajar. Teknik pengumpulan data adalah teknik nontes dan teknik tes. Alat pengumpulan data adalah lembar observasi dan soal ulangan harian. Teknik analisis data adalah deskriptif komparatif. Data berupa hasil belajar dianalisis secara deskriptif komparatif dengan indikator keberhasilan tindakan, yaitu nilai rata-rata dan ketuntasan minimal. Nilai rata-rata hasil belajar dibandingkan dengan Kriteria Ketuntasan Minimal (KKM), yaitu 75. Sedangkan ketuntasan kelas dibandingkan dengan ketuntasan minimal, yaitu $80 \%$.

\section{Hasil Penelitian}

Pada Kondisi Awal, pembelajaran berlangsung klasikal. Dengan kelas yang besar dan metode belajar ceramah berpusat pada guru, perhatian siswa menjadi kurang dan kelas tidak kondusif. Selain itu, pembelajaran yang berpusat pada guru ini berlangsung dengan penjelasan yang bersifat abstrak dan cepat. Walaupun pembelajaran ditunjang dengan alat peraga dan media pembelajaran, siswa mengalami kesulitan belajar, tidak dapat mengungkapkan pendapat dan takut bertanya. Siswa mengalami kesulitan dalam penguasaan materi tentang globalisasi dan kebudayaan.

Sesuai dengan nilai ulangan harian, analisis hasil belajar menunjukkan nilai ratarata sebesar 64,46 dan ketuntasan sebesar 14,28\%. Analisis hasil belajar secara lengkap sebagai berikut:

Tabel 1. Analisis hasil belajar pada Kondisi Awal.

\begin{tabular}{lccc}
\hline \multicolumn{1}{c}{ Hasil belajar } & Keterangan & Indikator & Keputusan \\
\hline Nilai terendah & 50 & & \\
Nilai rata-rata & 64,46 & 75 & Tidak memenuhi \\
Nilai tertinggi & 80 & & \\
Jumlah tuntas & 4 & & \\
Ketuntasan & $14,28 \%$ & $80 \%$ & Tidak memenuhi \\
\hline
\end{tabular}

Sesuai dengan analisis di atas, maka nilai rata-rata adalah lebih rendah daripada KKM dan ketuntasan kelas adalah lebih rendah daripada ketuntasan minimal. Hasil belajar termasuk rendah. Atas dasar tersebut, penulis melakukan tindakan dengan metode diskusi. 
Pada Siklus I, pembelajaran berlangsung dalam kelompok. Siswa dibagi menjadi 4 kelompok, sehingga masing-masing terdiri dari 7 anggota. Komposisi kelompok termasuk besar dengan anggota lebih daripada 5. Penugasan pada siswa adalah menyusun kliping tentang budaya Indonesia yang berkaitan dengan makanan tradisional, permainan tradisional dan tarian tradisional. Hasil kliping masing-masing kelompok sebagai materi diskusi dalam kelompok. Diskusi berlangsung di dalam kelas. Sesuai dengan hasil diskusi kelompok, masing-masing perwakilan kelompok melakukan presentasi secara berurutan. Hasil penugasan tersebut adalah Kelompok I dan II dengan nilai B dan Kelompok III dan IV dengan nilai $\mathrm{C}$.

Sesuai dengan nilai ulangan harian, analisis hasil belajar menunjukkan nilai ratarata sebesar 74,28 dan ketuntasan sebesar 60,71\%. Analisis hasil belajar secara lengkap sebagai berikut:

Tabel 2. Analisis hasil belajar pada Siklus I.

\begin{tabular}{lccc}
\hline \multicolumn{1}{c}{ Hasil belajar } & Keterangan & Indikator & Keputusan \\
\hline Nilai terendah & 60 & & \\
Nilai rata-rata & 74,28 & 75 & Tidak memenuhi \\
Nilai tertinggi & 90 & & \\
Jumlah tuntas & 17 & & \\
Ketuntasan & $60,71 \%$ & $80 \%$ & Tidak memenuhi \\
\hline
\end{tabular}

Sesuai dengan analisis di atas, maka nilai rata-rata adalah lebih rendah daripada KKM dan ketuntasan kelas adalah lebih rendah daripada ketuntasan minimal. Hasil belajar termasuk rendah. Hasil belajar mengalami peningkatan, namun belum optimal. Atas dasar tersebut, penulis melanjutkan tindakan pada Siklus II

Pada Siklus II, pembelajaran berlangsung dalam kelompok yang sama seperti pada pembelajaran Siklus I. Penugasan pada siswa adalah menyusun kliping tentang budaya Indonesia yang ditampilkan di tingkat internasional. Hasil kliping masing-masing kelompok sebagai materi diskusi dalam kelompok. Diskusi berlangsung di luar kelas. Sesuai dengan hasil diskusi kelompok, masing-masing perwakilan kelompok melakukan presentasi secara berurutan. Hasil penugasan tersebut adalah Kelompok I, II, III dan IV dengan nilai B.

Sesuai dengan nilai ulangan harian, analisis hasil belajar menunjukkan nilai ratarata sebesar 84,46 dan ketuntasan sebesar 96,42\%. Analisis hasil belajar secara lengkap sebagai berikut:

Tabel 3. Analisis hasil belajar pada Siklus II.

\begin{tabular}{lccc}
\hline \multicolumn{1}{c}{ Hasil belajar } & Keterangan & Indikator & Keputusan \\
\hline Nilai terendah & 70 & & \\
Nilai rata-rata & 84,46 & 75 & Memenuhi \\
Nilai tertinggi & 100 & & \\
Jumlah tuntas & 27 & & \\
Ketuntasan & $96,42 \%$ & $80 \%$ & Memenuhi \\
\hline
\end{tabular}

Sesuai dengan analisis di atas, maka nilai rata-rata adalah lebih tinggi daripada KKM dan ketuntasan kelas adalah lebih tinggi daripada ketuntasan minimal. Hasil belajar termasuk tinggi. Hasil belajar mengalami peningkatan secara optimal. Atas dasar tersebut, penulis menghentikan tindakan pada Siklus II. 


\section{Pembahasan}

Penerapan penugasan dengan metode diskusi kelompok dalam mata pelajaran PKn tentang budaya Indonesia dengan penugasan dan diskusi kelompok. Penugasan bersifat individual yang dilakukan oleh siswa. Penugasan dengan menyusun kliping. Hasil penugasan tersebut disesuaikan dengan materi dan digunakan sebagai bahan dalam diskusi dengan kelompok. Hasil diskusi kelompok digunakan sebagai bahan presentasi oleh perwakilan kelompok.

Sesuai dengan subyek penelitian, maka ada 4 kelompok yang terdiri dari 7 anggota. Komposisi kelompok ini termasuk kelompok besar dengan anggota yang lebih daripada 5 anggota. Namun dengan komposisi anggota yang besar ini pula memudahkan anggota dalam melakukan tugas di rumah. Hasil tugas menjadi lebih ringan bagi anggota. Hasil tugas juga semakin beragam.

Pada Siklus I, penugasan adalah kliping tentang budaya Indonesia yang berkaitan dengan makanan tradisional, permainan tradisional dan tarian tradisional. Diskusi kelompok berlangsung di dalam kelas. Sedangkan pada Siklus II, penugasan adalah kliping tentang budaya Indonesia yang ditampilkan di tingkat internasional. Diskusi kelompok berlangsung di luar kelas.

Sesuai dengan penerapan penugasan dengan metode diskusi kelompok, nilai ulangan harian meningkat pada tiap siklus. Analisis hasil belajar secara lengkap sebagai berikut:

Tabel 4. Analisis hasil belajar pada Kondisi Awal, Siklus I dan Siklus II.

\begin{tabular}{clccc}
\hline No & Hasil Belajar & Kondisi Awal & Siklus I & Siklus II \\
\hline 1 & Nilai terendah & 50 & 60 & 70 \\
2 & Nilai rata-rata & $64,46<75$ & $74,28<75$ & $84,46>75$ \\
3 & Nilai tertinggi & 80 & 90 & 100 \\
4 & Jumlah tuntas & 4 & 17 & 27 \\
5 & Ketuntasan & $14,28 \%<80 \%$ & $60,71 \%<80 \%$ & $96,42 \%>80 \%$ \\
\hline
\end{tabular}

Sesuai dengan tabel 4 , maka hasil belajar mengalami peningkatan. Nilai terendah semakin meningkat, dari 50 menjadi 70. Begitu juga dengan nilai tertinggi juga semakin meningkat, dari 80 menjadi 100. Hasil belajar pada Siklus I mengalami peningkatan, namun belum optimal. Sedangkan hasil belajar pada Siklus II mengalami peningkatan secara optimal. Hasil belajar pada Siklus II memenuhi indikator keberhasilan tindakan, yaitu nilai rata-rata memenuhi KKM sebesar 75 . Hal yang sama juga terjadi pada ketuntasan, yaitu ketuntasan memenuhi ketuntasan minimal sebesar $80 \%$.

Keberhasilan tindakan dalam pembelajaran tersebut sesuai dengan kelebihan dari metode diskusi kelompok, yaitu 1) masalah dapat dipecahkan dengan berbagai jalan, bukan hanya satu jalan, 2) saling mengemukakan pendapat secara konstruktif, sehingga diperoleh keputusan yang lebih baik, 3) membiasakan mendengarkan pendapat orang lain, sekalipun berbeda pendapat dan bersikap toleran (Djamarah, 2010: 199), 4), 5) suasana kelas lebih hidup, 6) menaikkan prestasi kepribadian individu, 7) kesimpulan hasil diskusi mudah dipahami, 8) belajar mematuhi peraturan dan tata tertib dalam musyawarah (Zuharini, 2003: 
90), 9) bertukar pikiran, 10) menghayati permasalahan, 11) mengembangkan tanggung jawab dan solidaritas, 12) membina kemampuan berbicara, 13) belajar memahami pikiran orang lain dan 13) memberikan kesempatan belajar (Madjid, 2011: 142).

Menurut Sahnun (2018), kelemahan metode diskusi adalah tidak dapat dipakai untuk kelompok besar. Hal tersebut juga terjadi dalam penelitian ini dimana siswa dibagi dalam empat kelompok, dimana kelompok terdiri dari tujuh anggota. Jumlah anggota sebanyak tujuh anak termasuk kelompok besar. Kelemahan tersebut terbukti pada Siklus I dimana hasil tugas kelompok hanya memperoleh nilai C. Sesuai dengan tindakan dalam pembelajaran, maka siswa menyesuaikan diri dengan baik pada Siklus II dan memperoleh hasil tugas kelompok yang lebih baik, yaitu nilai B. Dengan demikian, kelemahan pada metode diskusi teratas.

Penerapan metode diskusi kelompok tidak boleh dianggap remeh. Untuk mencapai hasil yang optimal, ada sejumlah hal yang harus diperhatikan (Suwarto, 2009). Sanjaya (2011: 158-159), penerapan metode diskusi meliputi persiapan, pelaksanaan dan penutupan. Masing-masing tahap adalah penting, sehingga kelebihan dari metode diskusi menjadi optimal. Sesuai dengan hal tersebut, penulis benar-benar memperhatikan masing-masing tahap. Tindakan dalam penelitian ini difokuskan pada pelaksanaan, yaitu di dalam kelas untuk Siklus I dan di luar kelas pada Siklus II. Hasilnya adalah peningkatan nilai rata-rata dan ketuntasan. Sesuai dengan analisis data tersebut, maka hasil belajar mengalami peningkatan dan memenuhi indikator keberhasilan tindakan. Dengan demikian, tindakan dalam pembelajaran berhasil dan hipotesis penelitian terbukti benar, yaitu penguasaan mata pelajaran PKn tentang budaya Indonesia melalui penugasan dengan diskusi kelompok pada Siswa Kelas IV SD Negeri Karanglincak meningkatkan hasil belajar.

\section{Simpulan dan Saran}

Simpulan dalam penelitian ini adalah penerapan penugasan dengan metode diskusi kelompok di dalam kelas dan di luar kelas meningkatkan hasil belajar siswa. Hasil belajar meningkat sesuai dengan peningkatan nilai rata-rata dan ketuntasan. Nilai rata-rata memenuhi Kriteria Ketuntasan Minimal (KKM) sebesar 75 dan ketuntasan memenuhi ketuntasan minimal sebesar $80 \%$.

\section{Daftar Rujukan}

Djamarah, SB. (2010). Guru dan Anak Didik dalam Interaksi Edukatif. Jakarta: Rineka Cipta.

Madjid, A. (2011). Perencanaan Pembelajaran. Bandung: Remaja Rosdakarya.

Masitoh. (2009). Strategi Pembelajaran. Jakarta: Direktorat Pendidikan Islam Departemen Agama Republik Indonesia.

Mujinem. (2018). Peningkatan Pemahaman, Keterampilan Berpikir dan Sikap Demokratis

Siswa dengan Metode Diskusi Kelompok dalam Pembelajaran PKn di Kelas XI L1

SMK N 3 Kasihan. Jurnal Ilmiah Guru, volume 16(2), Hal: 49-58.

Sanjaya, W. (2011). Strategi Pembelajaran Berorientasi Standar Proses Pendidikan. Jakarta: Kencana.

Syah, M. (2007). Psikologi Pendidikan dengan Pendekatan Baru. Bandung: Remaja Rosdakarya. 
Syafril. (2019). Peningkatan Pemahaman Materi Globalisasi melalui Metode Diskusi Kelompok Kelas IV SD Negeri 10 Krueng Sabe. Serambi Akademica, volume 7(1), Hal: 9-19.

Sahnun. (2018). Efektivitas Metode Diskusi dalam Meningkatkan Hasil Belajar PKn Materi Menjelaskan Proses Pemilu dan Pilkada pada Siswa Kelas VI SDN 7 MontongBaan. El Tsaqafah, volume 17(2), Hal: 221-238.

Suwarto, S. (2009). Pengembangan tes dan analisis hasil tes yang terintegrasi dalam program komputer. Jurnal Penelitian dan Evaluasi Pendidikan, 13(1), 40-56.

Suwarto, S. (2017). Pengembangan tes ilmu pengetahuan alam terkomputerisasi. Jurnal Penelitian dan Evaluasi Pendidikan, 21(2), 153-161.

Wagiyem. (2021). Peningkatan Hasil Belajar PPKn Materi Tata Tertib Model Make a Match Siswa Kelas I SDN Bendosari 03 Tahun Pelajaran 2018/2019. Jurnal Pendidikan, volume 29(1), Hal: 123-132.

Warsini. (2020). Model Pembelajaran Kooperatif Tipe Think Pair Share (TPS) sebagai Upaya Meningkatkan Prestasi Belajar PKn Siswa Kelas IXC Semester 1 SMP Negeri 2 Nguter Tahun Pelajaran 2017/2018. Jurnal Pendidikan, volume 29(3), Hal: 279-286.

Zuharini. (2003). Metodik Khusus Pendidikan Agama. Surabaya: Usaha Nasional. 